\title{
TARGET DAN REALISASI PAJAK DAERAH DI KABUPATEN MINAHASA UTARA
}

\author{
Marini Loho \\ Charles R. Ngangi \\ Caroline B. D. Pakasi
}

\begin{abstract}
The objective of the research is to analyze the target and realization of tax revenue in North Minahasa Regency. The study was conducted from September to November of 2017. The data used were secondary data. Data collection techniques used are to go directly to the local revenue department and conduct interviews and make the necessary data recording. Method of data processing using trend analysis method. The results of the research showed that the Local Tax has a great influence on development in North Minahasa Regency and Development in North Minahasa Regency. It is increasingly seen clearly, in the construction of housing, warehouses and tourist places. It can also be seen from tax return projection for the next five years that is alwasy growing every year. jnkd $^{*}$.
\end{abstract}

Keywords: target and realization, area tax, North Minahasa Regency

\begin{abstract}
ABSTRAK
Tujuan penelitian adalah untuk menganalisis target dan realisasi penerimaan pajak di Kabupaten Minahasa Utara. Penelitian dilaksanakan dari bulan September sampai bulan November tahun 2017. Data yang digunakan adalah data sekunder. Teknik pengumpulan data yang digunakan adalah dengan mendatangi langsung dinas pendapatan daerah dan melakukan wawancara serta melakukan pencatatan data yang diperlukan. Metode pengolahan data menggunakan metode analisis trend. Hasil penelitian menunjukkan bahwa Pajak Daerah mempunyai pengaruh yang besar terhadap pembangunan di Kabupaten Minahasa Utara serta Pembangunan di Daerah Kabupaten Minahasa Utara. Hal ini dapat terlihat jelas, dalam pembangunan perumahan, gudang dan tempat - tempat wisata. Dapat dilihat juga dari hasil proyeksi pajak untuk lima tahun ke depan yang selalu mengalami pertumbuhan setiap tahunnya.*jnkd*.
\end{abstract}

Kata kunci: target dan realisasi, pajak daerah, Kabupaten Minahasa Utara.

\section{PENDAHULUAN}

\section{Latar Belakang}

Penerapan otonomi daerah di Indonesia telah memberikan kewenangan yang lebih luas kepada setiap daerah untuk melakukan berbagai upaya mengembangkan wilayahnya berdasarkan potensi yang dimiliki. Dengan kewenangan tersebut diharapakan pengembangan wilayah akan sesuai dengan karakteristik wilayah tersebut. Pengembangan wilayah merupakan suatu upaya untuk mendorong terjadinya perkembangan wilayah secara harmonis mencakup fisik, ekonomi, sosial dan budaya. Pada dasarnya pengembangan wilayah ini di gunakan untuk lebih mengefisiensikan pembangunan daerah sesuai dengan kondisi wilayahnya.

Pengembangan wilayah mulai di pandang sebagai solusi untuk mempercepat pembangunan daerah. Pembangunan daerah merupakan seluruh pembangunan yang 
dilaksanakan di daerah dan meliputi aspek kehidupan masyarakat. Pembangunan daerah diarahkan untuk memanfaatkan secara maksimal potensi sumber daya yang ada di suatu daerah. Salah satu tujuan pembangunan daerah yaitu untuk meningkatkan pendapatan atau penerimaan daerah dan kesejateraan masyarakat. Membicarakan tentang pembangunan daerah maka sangat erat kaitannya dengan pendapatan daerah. Dan pendapatan daerah masih merupakan elemen yang cukup penting peranannya baik untuk mendukung penyelenggaraan pemerintah maupun pemberian pelayanan kepada publik. Pendapatan daerah masih merupakan alternatif pilihan utama dalam mendukung program dan kegiatan penyelenggaraan pemerintahan dan pelayanan yaitu untuk pembangunan daerah.

Salah satu sumber pendapatan daerah yang penting untuk membiayai pelaksanaan pemerintahan daerah dan untuk pembangunan daerah serta untuk meningkatkan pelayanan kepada masyarakat yaitu perlu di lakukan pemungutan pajak. Menurut Rochmat (2012), pajak adalah iuran rakyat pada kas negara berdasrkan Undang-Undang (yang di paksakan) dengan tidak mendapat jasa timbal yang langsung dapat di tunjukkan dan yang di gunakan untuk membayar pengeluaran umum, sedangkan menurut (Brotodiharjo 2011), pajak iuran rakyat kepada negara (yang dapat dipaksakan) yang terutang oleh wajib pajak membayarnya berdasarkan peraturanperaturan, dengan tidak mendapat prestasi kembali yang langsung dapat ditunjuk dan yang dapat di gunakan untuk membiayai pengeluaran umum berhubungan dengan tugas negara untuk menyelenggarakan pemerintah. Berbagai macam jenis pungutan pajak disuatu daerah yang menjadi sumber pendapatan adalah pajak penghasilan, pajak pertambahan nilai, pajak penjualan atas barang mewah, pajak bumi dan bangunan, pajak hotel, pajak restoran, pajak hiburan, pajak reklame, dan pajak penerangan jalan. Pentingnya pajak sebagai sumber pembiayaan pembangunan suatu daerah telah ditetapkan dalam perundang - undangan pemerintah.

Mengingat pentingnya peranan pajak dalam meningkatkan Pendapatan Asli Daerah, maka di berikan kepada daerah suatu kewenangan untuk menetapkan tarif pajak daerah dengan batasan tarif minimum dan maksimum. Menurut Undang - Undang Nomor 28 Tahun 2009, Pendapatan Asli Daerah merupakan salah satu sumber dana pembiayaan pembagunan daerah pada kenyataannya belum cukup memberikan sumbangan bagi pertumbuhan daerah, hal ini mengharuskan pemerintah daerah menggali dan meningkatkan pendapatan daerah terutama sumber pendapatan asli daerah yang salah satunya bersumber dari pajak daerah yang bertujuan untuk memberikan keluasan kepada daerah dalam menggali pendanaan dalam upaya memperbesar peran pemerintah daerah dalam pembangunan.

Mengetahui kondisi eksisting penerimaan daerah yang salah satunya bersumber dari pajak, maka daerah Kabupaten Minahasa Utara juga melakukan dan mengoptimalkan pemungutan pajak di Kabupaten Minahasa Utara. Pemerintah Kabupaten Minahasa Utara setiap tahunnya mempunyai target dalam penerimaan pajak sebagai sumber pendapatan yang diharapkan melalui peningkatan realisasi dalam penerimaan pajak dapat memacu pembangunan daerah dan pembangunan ekonomi di Kabupaten Minahasa Utara.

\section{Rumusan Masalah}

Bagaimana target dan realisasi pajak yang ada di Kabupaten Minahasa Utara?

\section{Tujuan Penelitian}

Menganalisis target dan realisasi penerimaan pajak di Kabupaten Minahasa Utara.

\section{Manfaat Penelitian}

Sebagai bahan referensi untuk penelitian-penelitian yang akan datang. 


\section{METODE PENELITIAN}

Waktu dan Tempat Penelitian

Penelitian ini dilakukan di Kabupaten Minahasa Utara. Penelitian dilaksanakan dari bulan September sampai bulan November tahun 2017 mulai dari persiapan, pengambilan data sampai penyusunan laporan dan ujian sarjana.

\section{Jenis Data dan Sumber Data}

\section{Jenis Data}

Data kuantitatif yang digunakan dalam penelitian ini adalah target dan realisasi penerimaan pajak dari tahun 2012 - 2016 yang di peoleh dari instansi yang terkait.

\section{Sumber Data}

Dalam penelitian ini menggunakan data sekunder yang berupa data - data target dan realisasi penerimaan pajak yang di peroleh dari objek penelitian melalui instansi yang terkait.

\section{Teknik Pengumpulan Data}

Teknik pengumpulan data yang digunakan dalam penelitian ini adalah dengan mendatangi langsung pada dinas pendapatan daerah dan melakukan wawancara serta melakukan pencatatan data yang diperlukan.

\section{Konsep Pengukuran Variabel}

Target merupakan sasaran atau batas ketentuan yang telah ditetapkan untuk dicapai. Dengan indikatornya adalah target yang di telah di tentukan oleh daerah $(\mathrm{Rp})$

Realisasi merupakan tindakan yang nyata atau adanya pergerakan atau perubahan dari rencana yang sudah dibuat atau di kerjakan. Dengan indikatornya adalah realisasi yang telah di capai $(\mathrm{Rp})$.

\section{Metode Analisis Data}

Metode analisis data yang digunakan yaitu analisis data kuantitatif tentang target dan realisasi pajak. Data yang terkait di peroleh dari instansi yang terkait dalam penelitian ini. Analisis data dilakukan dengan tahapan mengambil data yang terkait dengan pajakpajak yang ada di Kabupaten Minahasa Utara dan menghitung masing-masing relisasi pajak dari tahun 2012-2016.

\section{HASIL DAN PEMBAHASAN}

\section{Gambaran Kabupaten Minahasa Utara}

Kabupaten Minahasa Utara merupakan salah satu Kabupaten pemekaran di Provinsi Sulawesi Utara. Pemekaran Kabupaten Minahasa Utara dari Kabupaten Minahasa Induk, diharapkan akan mengakselerasi pertumbuhan dan pembangunan daerah. Ibukota Kabupaten Minahasa Utara adalah Airmadidi yang berjarak sekitar $12 \mathrm{~km}$ dari Kota Manado, ibukota Provinsi Sulawesi Utara.

Posisi Kabupaten Minahasa Utara diapit oleh dua Kota yaitu Kota Manado dan Kota Bitung, kawasan ini lebih dikenal sebagai kawasan Pengembangan Ekonomi Terpadu (KAPET) Manado-Bitung. Hal ini, secara geografis posisi tersebut memberikan efek positif bagi percepatan pembangunan Minahasa Utara ke depan.

Kabupaten Minahasa Utara adalah salah satu Kabupaten di Provinsi Sulawesi Utara dengan Ibukota Kabupaten Minahasa Utara yaitu Airmadidi, berjarak sekitar $12 \mathrm{~km}$ dari Manado, ibukota Provinsi Sulawesi Utara. Dari segi letak Kabupaten Minahasa Utara cukup strategis karena berada di antara dua Kota utama yaitu Kota Manado dan Kota Bitung. Wilayah Kabupaten ini mempunyai batas-batas sebagai berikut :

a. Sebelah Utara dengan Kabupaten Sitaro dan Laut Sulawesi.

b. Sebelah Timur dengan Kota Bitung dan Laut Maluku;

c. Sebelah Selatan dengan Kabupaten Minahasa;

d. Sebelah Barat dengan Kota Manado.

Kabupaten Minahasa Utara tediri dari 10 Kecamatan yakni Kecamatan (1) Kema; (2) Kauditan; (3) Airmadidi; (4) Kalawat; (5) Dimembe; (6) Talawaan; (7) Wori; (8)Likupang Barat; (9) Likupang Timur dan (10) Likupang Selatan.

\section{Faktor Pembangunan}

\section{Sumber Daya Manusia}

Salah satu keberhasilan pembangunan yang ada di suatu wilayah adalah apabila di dukung oleh sumber daya manusia yang 
berkualitas. Melalui jalur pendidikan pemerintah berupaya untuk menghasilkan dan meningkatkan kualitas sumber daya manusia. Pendidikan adalah faktor penting untuk membentuk Sumber Daya Manusia (SDM) yang berkualitas untuk mendukung keberhasilan pembangunan di suatu wilayah. Peningkatan SDM sekarang ini difokuskan pada pemberian kesempatan seluas-luasnya kepada penduduk untuk mengecap pendidikan, terutama penduduk pada kelompok umur sekolah (umur 7-24 tahun).

Tabel 1. Jumlah Sekolah Di Minahasa Utara Tahun 2016

\begin{tabular}{|c|c|c|c|c|c|}
\hline \multirow[t]{2}{*}{ No. } & \multirow[t]{2}{*}{ Kecamatan } & \multicolumn{4}{|c|}{ Jumlah Sekolah } \\
\hline & & TK & $\mathrm{SD}$ & SMP & SMA \\
\hline 1. & Kema & 0 & 16 & 7 & 0 \\
\hline 2. & Kauditan & 0 & 24 & 8 & 0 \\
\hline 3. & Airmadidi & 0 & 21 & 6 & 0 \\
\hline 4. & Kalawat & 0 & 16 & 5 & 0 \\
\hline 5. & Dimembe & 0 & 23 & 4 & 0 \\
\hline 6. & Taalwaan & 0 & 18 & 5 & 0 \\
\hline 7. & Wori & 0 & 8 & 8 & 0 \\
\hline 8. & Likupang Barat & 0 & 22 & 12 & 0 \\
\hline 9. & Likupang Timur & 0 & 23 & 10 & 0 \\
\hline 10. & Likupang Selatan & 0 & 8 & 3 & 0 \\
\hline & Jumlah & 0 & 193 & 68 & 0 \\
\hline
\end{tabular}

Sumber : Minahasa Utara Dalam Angka 2017

Tabel 1 menunjukkan jumlah sarana pendidikan yang tersedia di Kabupaten Minahasa Utara yang tersebar pada 10 kecamatan ada 261 unit sarana pendidikan dari jenjang pendiidkan SD dan SMA. Tercatat ada sebanyak 193 Sekolah Dasar dan 68 Sekolah Menengah Pertama, namun pada tahun 2016 tidak ada Sekolah Taman KanakKanak dan Sekolah Menengah Atas di 10 kecamatan yang ada di Kabupaten Minahasa Utara.

\section{Target dan Realisasi Pajak Daerah Kabupaten Minahasa Utara Tahun 2012 - 2016}

Kabupaten Minahasa Utara memiliki target dan realisasi pajak yang telah terlaksana pada tahun 2012 - 2016. Target dan realisasi pajak secara rinci dapat dilihat pada Tabel 2.
Tabel 2. Target dan Realisasi Pajak Hotel Kabupaten Minahasa Utara Tahun 2012-2016

\begin{tabular}{crrr}
\hline Tahun & \multicolumn{1}{c}{ Target } & \multicolumn{1}{c}{ Realisasi } & \multicolumn{1}{c}{$\%$} \\
\hline 2012 & 867.180 .000 & 593.931 .004 & 68,49 \\
2013 & 487.000 .000 & 549.862 .872 & 112,91 \\
2014 & 805.000 .000 & 746.875 .269 & 92,78 \\
2015 & 1.681 .078 .927 & 1.682 .057 .509 & 100,06 \\
2016 & 1.362 .499 .565 & 990.137 .674 & 72,67 \\
\hline
\end{tabular}

Sumber: Dinas Pendapatan Daerah Kabupaten Minahasa Utara

Tabel 2 menunjukkan bahwa realisasi pajak yang paling tinggi ada pada tahun 2013, yaitu sebesar 549.862.872 dan realisasi yang paling sedikit yaitu terjadi pada tahun 2012, yaitu hanya mencapai 593.931.004.

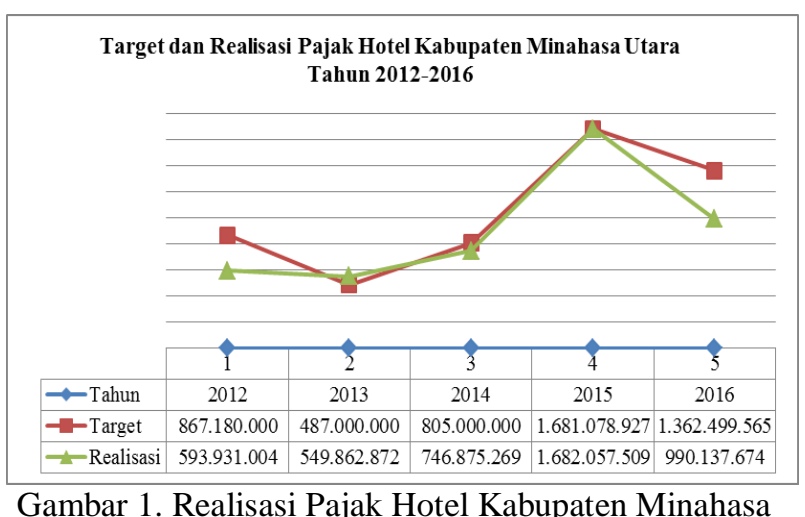
Utara Tahun 2012-2016

Gambar 1 menunjukkan bahwa realisasi dari pajak hotel mengalami naik turun. Pada tahun 2012, 2014 dan 2016 realisasinya tidak melebihi target sedangkan pada tahun 2013 dan 2015 realisasinya mencapai bahkan melebihi target.

Tabel 3. Target dan Realisasi Pajak Restoran Kabupaten Minahasa Utara Tahun 2012-2016

\begin{tabular}{crrr}
\hline Tahun & \multicolumn{1}{c}{ Target } & \multicolumn{1}{c}{ Realisasi } & \multicolumn{1}{c}{$\%$} \\
\hline 2012 & 841.980 .000 & 637.458 .610 & 75,71 \\
2013 & 500.000 .000 & 466.373 .758 & 93,27 \\
2014 & 1.370 .000 .000 & 1.680 .427 .348 & 122,66 \\
2015 & 3.715 .576 .505 & 4.049 .006 .917 & 108,97 \\
2016 & 3.137 .883 .364 & 2.360 .015 .198 & 75,21 \\
\hline
\end{tabular}

Sumber: Dinas Pendapatan Daerah Kabupaten Minahasa Utara

Tabel 3 menunjukkan bahwa realisasi pajak yang paling tinggi ada pada tahun 2014, yaitu sebesar 1.680.427.5348 dan realisasi yang 
paling sedikit yaitu terjadi pada tahun 2016, yaitu hanya mencapai 2.360.015.198.

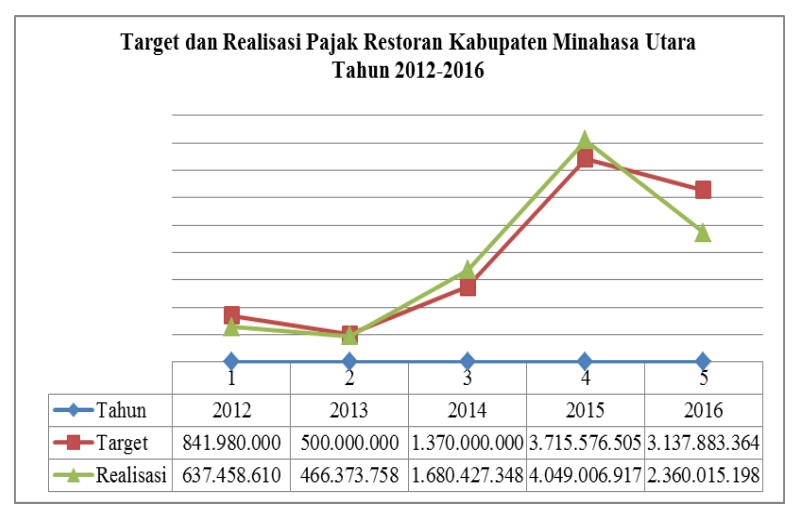

Gambar 2. Realisasi Pajak Restoran

Kabupaten Minahasa Utara Tahun 2012-2016

Gambar 2 menunjukkan bahwa realisasi dari pajak restoran realisasinya banyak yang tidak melebihi target, hal ini bisa di lihat pada tahun 2012, 2013 dan 2016.

\begin{tabular}{crrr} 
Tabel 4. Target dan Realisasi Pajak Hiburan & Kabupaten Minahasa Utara Tahun \\
& 2012-2016 \\
& \multicolumn{1}{c}{ Target } & \multicolumn{1}{c}{ Realisasi } & \multicolumn{1}{c}{$\%$} \\
\hline Tahun & \multicolumn{1}{c}{ Tara } \\
\hline 2012 & 15.175 .000 & 5.039 .568 & 33,21 \\
2013 & 6.692 .500 & 3.336 .267 & 49,85 \\
2014 & 50.000 .000 & 7.976 .750 & 15,95 \\
2015 & 216.030 .186 & 216.389 .217 & 100,17 \\
2016 & 205.000 .000 & 150.569 .197 & 73,45 \\
\hline
\end{tabular}

Sumber: Dinas Pendapatan Daerah Kabupaten Minahasa Utara

Tabel 4 menunjukkan bahwa realisasi pajak yang paling tinggi ada pada tahun 2015 , yaitu sebesar 216.389.217 dan realisasi yang paling sedikit yaitu terjadi pada tahun 2014, yaitu hanya mencapai 7.976.750.

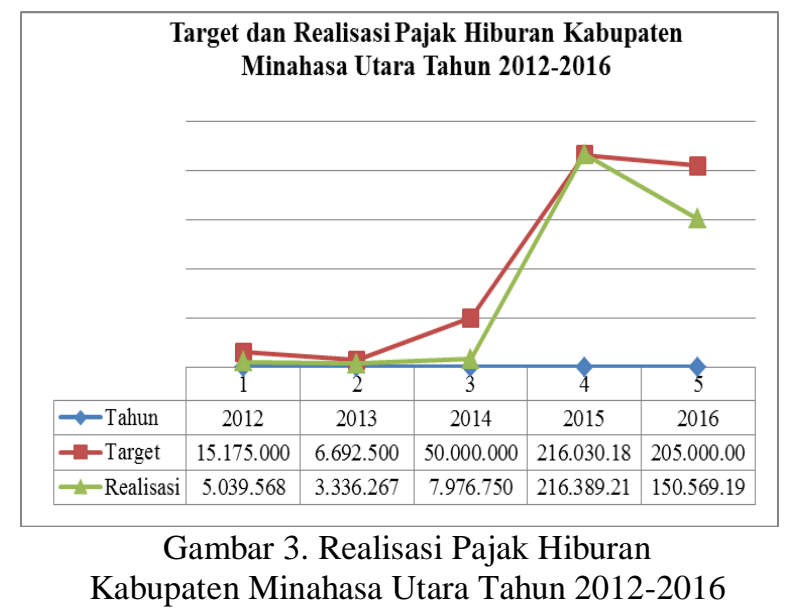

Gambar 3 menunjukkan bahwa realisasi pajak hiburan sangat rendah karena selang tahun 2012 sampai dengan tahun 2016, hanya pada tahun 2015 yang realisasinya melebihi target, sedangkan pada tahun 2012, 2013, 2014 dan 2016, realisasinya sangat jauh dari target.

Tabel 5. Target dan Realisasi Pajak Reklame Kabupaten Minahasa Utara Tahun 2012-2016

\begin{tabular}{crrr}
\hline Tahun & \multicolumn{1}{c}{ Target } & \multicolumn{1}{c}{ Realisasi } & \multicolumn{1}{c}{$\%$} \\
\hline 2012 & 87.100 .000 & 82.049 .473 & 94,20 \\
2013 & 95.810 .000 & 67.911 .563 & 70,88 \\
2014 & 200.000 .000 & 154.194 .985 & 77,10 \\
2015 & 107.724 .969 & 127.284 .701 & 118,16 \\
2016 & 500.000 .000 & 462.916 .701 & 92,58 \\
\hline
\end{tabular}

Sumber: Dinas Pendapatan Daerah Kabupaten

Minahasa Utara

Tabel 5 menunjukkan bahwa realisasi pajak yang paling tinggi ada pada tahun 2015, yaitu sebesar 127.284.701 dan realisasi yang paling sedikit yaitu terjadi pada tahun 2013, yaitu hanya mencapai 67.911.563.

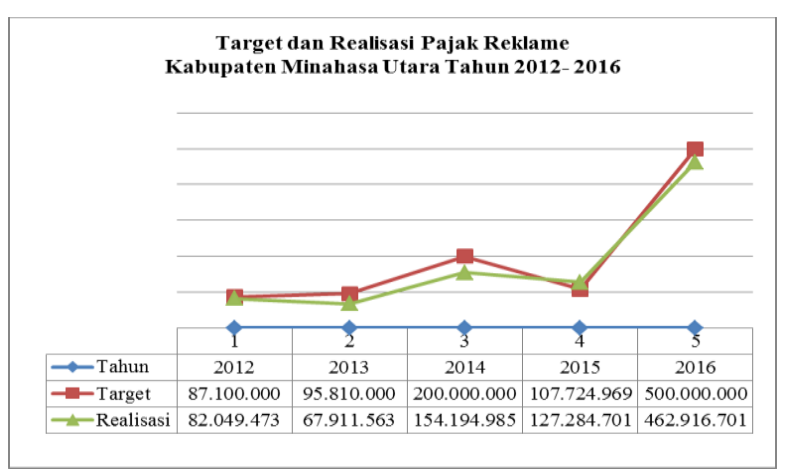

Gambar 4. Realisasi Pajak Reklame

Kabupaten Minahasa Utara Tahun 2012-2016

Gambar 4 menunjukkan bahwa realisasi yang di hasilkan pada pajak reklame ini sangat kurang, karena hanya pada tahun 2015 saja yang realisasinya melebihi target, sedangkan pada tahun 2012, 2013, 2014, dan 2016 realisasinya tidak melebihi target.

Tabel 6. Target dan Realisasi Pajak Penerangan Jalan Kabupaten Minahasa Utara Tahun 20122016

\begin{tabular}{cclr}
\hline Tahun & Target & Realisasi & \multicolumn{1}{c}{$\%$} \\
\hline 2012 & 400.000 .000 & 562.014 .130 & 134,18 \\
2013 & 600.000 .000 & 460.246 .278 & 97,50 \\
2014 & 600.000 .000 & 660.116 .110 & 94,34 \\
2015 & 600.000 .000 & 865.181 .048 & 114,42 \\
2016 & 142.147 .937 & 565.595 .031 & 92,58 \\
\hline
\end{tabular}

Sumber: Dinas Pendapatan Daerah Kabupaten Minahasa Utara 
Tabel 6 menunjukkan bahwa realisasi pajak yang paling tinggi ada pada tahun 2012, yaitu sebesar 4.562.014.130 dan realisasi yang paling sedikit yaitu terjadi pada tahun 2016, yaitu hanya mencapai 5.565.595.031.

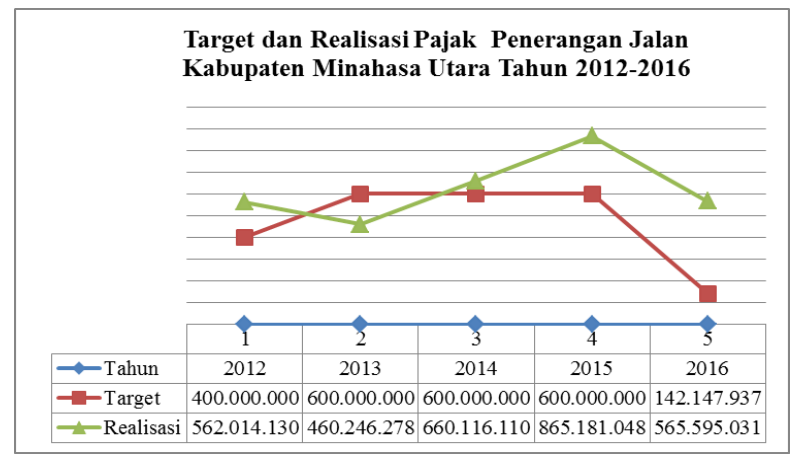

Gambar 5. Realisasi Pajak Penerangan Jalan

Kabupaten Minahasa Utara Tahun 2012-2016

Gambar 5 menunjukkan bahwa pajak penerangan jalan pada tahun 2012 dan tahun 2015 realisasinya melebihi target yang ada dan tahun 2013, 2014 dan 2016 realisasinya tidak melebihi target.

Tabel 7. Target dan Realisasi Pajak Mineral Bukan Logam dan Batuan Kabupaten Minahasa Utara Tahun 2012-2016

\begin{tabular}{crrr}
\hline Tahun & \multicolumn{1}{c}{ Target } & \multicolumn{1}{c}{ Realisasi } & \multicolumn{1}{c}{$\%$} \\
\hline 2012 & 650.000 .000 & 668.198 .270 & 102,80 \\
2013 & 677.158 .000 & 752.919 .608 & 111,19 \\
2014 & 1.000 .000 .000 & 1.088 .776 .090 & 108,88 \\
2015 & 1.000 .000 .000 & 1.018 .062 .400 & 101,81 \\
2016 & 1.000 .000 .000 & 633.186 .800 & 63,32
\end{tabular}

Sumber: Dinas Pendapatan Daerah Kabupaten Minahasa Utara

Tabel 7 menunjukkan bahwa realisasi pajak yang paling tinggi ada pada tahun 2013, yaitu sebesar 752.919.608 dan realisasi yang paling sedikit yaitu terjadi pada tahun 2016, yaitu hanya mencapai 633.186.800.

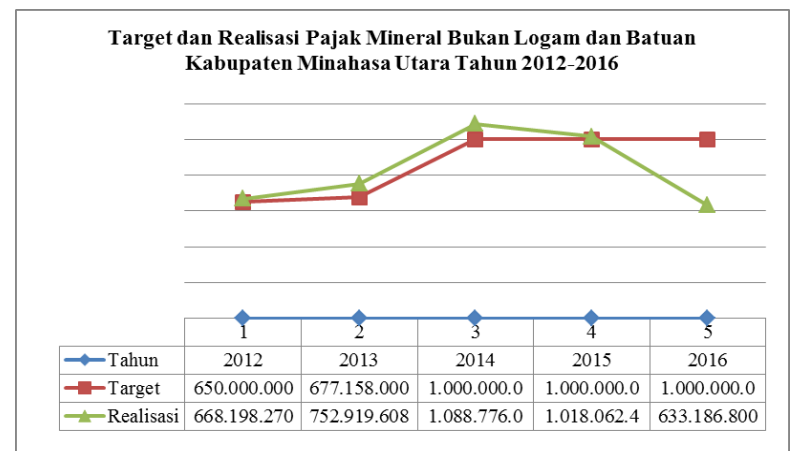

Gambar 6. Realisasi Pajak Mineral Bukan Logam dan Batuan Kabupaten Minahasa Utara Tahun 2012-2016
Gambar 6 menunjukkan bahwa realisasi pajak mineral bukan logam dan batuan sangat besar realisasinya. Pajak mineral bukan logam dan batuan dari tahun 2012 sampai dengan tahun 2015 realisasinya selalu melebihi target. Hanya pada tahun 2016 yang realisasinya tidak melebihi target.

Tabel 8. Target dan Realisasi Pajak Air Tanah Kabupaten Minahasa Utara Tahun 2012-2016

\begin{tabular}{crrr}
\hline Tahun & \multicolumn{1}{c}{ Target } & \multicolumn{1}{c}{ Realisasi } & \multicolumn{1}{c}{$\%$} \\
\hline 2012 & 321.000 .000 & 22.593 .977 & 7,04 \\
2013 & 849.653 .497 & 985.173 .798 & 115,95 \\
2014 & 2.500 .000 .000 & 1.675 .637 .190 & 67,03 \\
2015 & 1.324 .589 .413 & 1.819 .534 .003 & 137,37 \\
2016 & 1.586 .969 .134 & 1.293 .303 .014 & 81,50
\end{tabular}

Sumber: Dinas Pendapatan Daerah Kabupaten Minahasa Utara

Tabel 8 menunjukkan bahwa realisasi pajak yang paling tinggi ada pada tahun 2015, yaitu sebesar 1.819.534.003 dan realisasi yang paling sedikit yaitu terjadi pada tahun 2012, yaitu hanya mencapai 22.593.977.

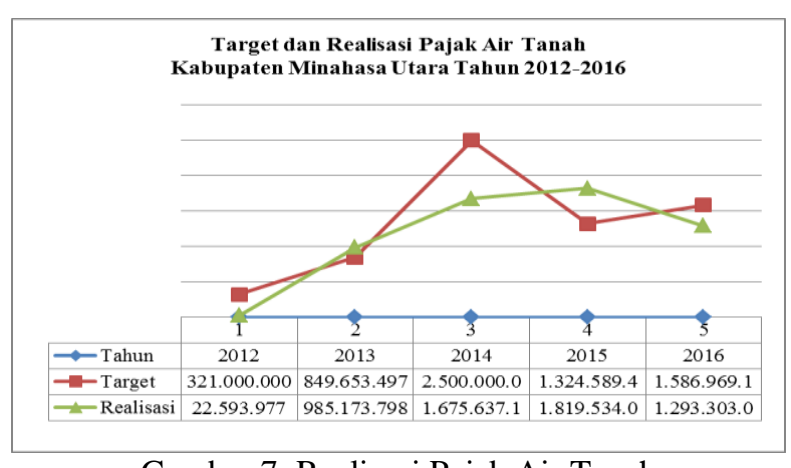

Gambar 7. Realisasi Pajak Air Tanah

Kabupaten Minahasa Utara Tahun 2012-2016

Gambar 7 menunjukkan bahwa realisasi pajak air tanah ini pada tahun 2012, 2014, 2015 dan tahun 2016 realisasinya tidak melebihi target, hanya pada tahun 2013 yang realisasinya melebihi target.

Tabel 9. Target dan Realisasi Pajak Sarang Burung Walet Kabupaten Minahasa Utara 2012-2016

\begin{tabular}{crrr}
\hline Tahun & \multicolumn{1}{c}{ Target } & \multicolumn{1}{c}{ Realisasi } & \multicolumn{1}{c}{$\%$} \\
\hline 2012 & 800.000 .000 & 1.000 .000 & 0,13 \\
2013 & 405.000 .000 & 42.140 .000 & 10,40 \\
2014 & 100.000 .000 & 23.539 .000 & 23,54 \\
2015 & 30.000 .000 & 25.339 .000 & 84,46 \\
2016 & & &
\end{tabular}

Sumber: Dinas Pendapatan Daerah Kabupaten Minahasa Utara 
Tabel 9 menunjukkan bahwa realisasi pajak yang paling tinggi ada pada tahun 2015, yaitu sebesar 25.339.000 dan realisasi yang paling sedikit yaitu terjadi pada tahun 2012, yaitu hanya mencapai 1.000 .000

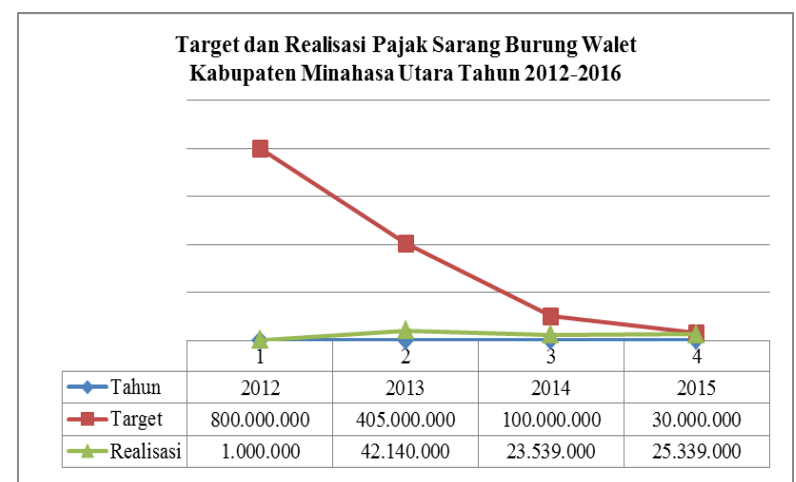

Gambar 8. Realisasi Pajak Sarang Burung Walet Kabupaten Minahasa Utara 2012-2016

Gambar 8 menunjukkan bahwa realisasi pajak sarang burung wallet merupakan pajak yang realisasinya sangat sedikit dan tidak mencapai target.

Tabel 10. Target dan Realisasi Pajak Bumi dan Bangunan Kabupaten Minahasa Utara Tahun 2012-2016

\begin{tabular}{cccr}
\hline Tahun & Target & Realisasi & \multicolumn{1}{c}{$\%$} \\
\hline 2012 & 0 & 0 & 0,00 \\
2013 & 0 & 0 & 0,00 \\
2014 & 3.000 .000 .000 & 3.488 .511 .406 & 116,28 \\
2015 & 4.850 .000 .000 & 4.891 .656 .315 & 100,86 \\
2016 & 4.900 .000 .000 & 3.189 .771 .898 & 65,10 \\
\hline
\end{tabular}

Sumber: Dinas Pendapatan Daerah Kabupaten

Minahasa Utara

Tabel 10 menunjukkan bahwa realisasi pajak yang paling tinggi ada pada tahun 2014, yaitu sebesar 4.891.656.315 dan realisasi yang paling sedikit yaitu terjadi pada tahun 2016, yaitu hanya mencapai 3.189.771.898.

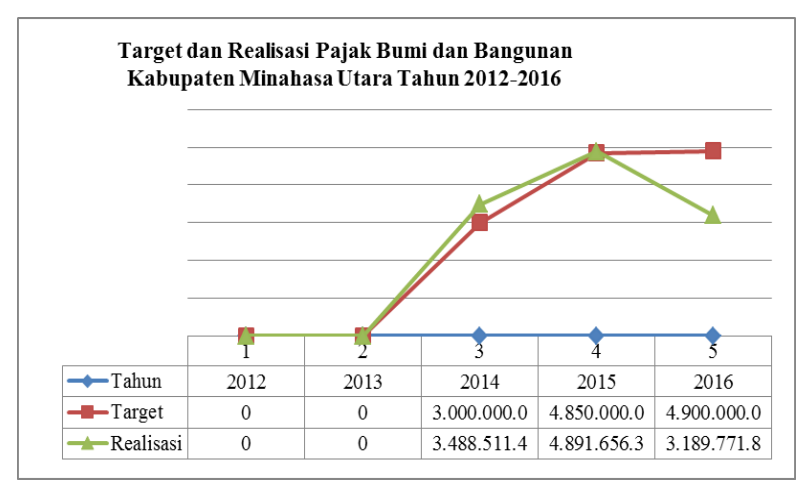

Gambar 9. Realisasi Pajak Bumi dan Bangunan Kabupaten Minahasa Utara Tahun 2012-2016
Gambar 9 menunjukkan bahwa pada tahun 2012 dan 2013 tidak ada data yang menampilkan target dan relisasi dari pajak bumi dan bangunan. Pada tahun 2014 dan 2015 realisasi dari pajak ini bisa melebihi target yang ada, sedangkan pada tahun 2016 realisisanya tidak mencapai target.

\begin{tabular}{ccccc} 
Tabel 11. & $\begin{array}{l}\text { Target dan } \\
\text { Perolehan } \\
\text { Banguan }\end{array}$ & $\begin{array}{l}\text { Realisasi atas } \\
\text { Kabupaten } \\
\text { Utara Tahun 2012-2016 }\end{array}$ & $\begin{array}{c}\text { Pajak } \\
\text { Tanah } \\
\text { Minahasa }\end{array}$ \\
& $\begin{array}{c}\text { Bea } \\
\text { dan }\end{array}$ \\
\hline Tahun & Target & Realisasi & $\%$ \\
\hline 2012 & 1.200 .000 .000 & 4.138 .410 .376 & 344,87 \\
2013 & 2.070 .000 .000 & 2.928 .828 .889 & 141,49 \\
2014 & 3.000 .000 .000 & 5.544 .046 .913 & 184,80 \\
2015 & 4.000 .000 .000 & 4.538 .850 .299 & 113,47 \\
2016 & 6.000 .000 .000 & 5.824 .296 .015 & 97,07 \\
\hline
\end{tabular}

Sumber: Dinas Pendapatan Daerah Kabupaten Minahasa Utara

Tabel 11 menunjukkan bahwa realisasi pajak yang paling tinggi ada pada tahun 2012, yaitu sebesar 4.138.410.376 dan realisasi yang paling sedikit yaitu terjadi pada tahun 2016, yaitu hanya mencapai 5.824.296.015

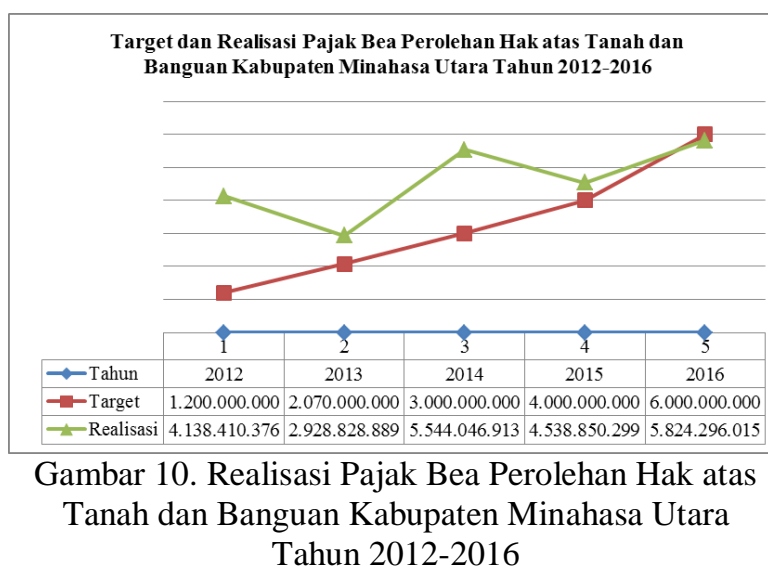

Gambar 10 menunjukkan bahwa realisasi pajak bea perolehan hak atas tanah dan bangunan sangat baik. Tahun 2012 sampai dengan tahun 2016 realisasi melebihi target dan hanya pada tahun 2016 yag realisasinya tidak melebihi target.

\section{Hubungan Antara Pajak dan Pembangunan}

Pajak merupakan faktor terpenting bagi keuangan suatu daerah dalam menjamin kelangsungan pembangunan suatu daerah. Semua sistem pajak akan mampu 
menggerakkan roda pembangunan suatu daerah. Pajak untuk pembangunan mempunyai 2 fungsi, yaitu fungsi budgetair dan fungsi mengatur atau regulerend. Sebagai fungsi budgetair, pajak merupakan sumber utama penerimaan negara yang akan digunakan untuk penerimaan negara yang akan digunakan untuk membiayai pengeluaran negara dan membiayai investasi pemerintah. Sebagai fungsi regulerend, pajak juga merupakan suatu sarana untuk mencapai tujuan - tujuan tertentu demi kesejahteraan rakyat, antara lain melalui pemerataan alokasi dan distribusi pendapatan serta tercapainya stabilitas ekonomi. Dengan demikian, jelas bahwa peranan penerimaan pajak bagi suatu daerah menjadi sangat dominan dalam menunjang jalannya pembiayaan pembangunan di suatu daerah.

Wujud nyata dari pajak yang di bayarkan dapat di lihat dari pembangunan sarana umum seperti jalan-jalan, jembatan, sekolah, rumah sakit atau puskesmas, dimana semua itu menggunakan uang yang berasal dari pajak. Di Kabupaten Minahasa Utara pun saat ini pemerintah tengah menggenjot pembangunan untuk mengembangkan daerah strategis. Dampak pembangunannya semakin dirasakan. Di Kabupaten Minahasa Utara ada tiga kecamatan yang menjadi kawasan dengan pertumbuhan yang cepat, yakni Kalawat, Airmadidi, dan Kauditan. Sementara itu, Kecamatan Likupang Timur, Likupang Barat, dan Kecamatan Wori termasuk daerah strategis untuk pengembangan di sektor budidaya perikanan, pariwisata dan pertambangan. Dan pembangunan yang dapat di lihat dengan jelas di daerah Kabupaten Minahasa Utara yaitu pembangunan perumahan yang berkembang di wilayah Kabupaten Minahasa Utara. Pada tahun 2012 lalu, pembangunan perumahan hanya dilakukan di Kecamatan Airmadidi, namun sejak beberapa tahun terakhir ini pembangunan mulai menjalar ke Kecamatan lainnya di Minahasa Utara antara lain, Kecamatan Talawaan, Kalawat, Airmadidi dan Kauditan. Selain perumahan, di
Kabupaten Minahasa Utara pun sudah mulai banyak bangunan pabrik dan objek wisata yang terkenal.

\section{KESIMPULAN DAN SARAN}

\section{Kesimpulan}

Realisasi penerimaan pajak Kabupaten Minahasa Utara pada tahun 2012-2016 terbesar di peroleh dari sektor Pajak Mineral Logam dan Batuan serta Pajak Hak Atas Tanah dan Bangunan, dimana hal ini melebihi target yang di tetapkan. Realisasi penerimaan pajak terkecil diperoleh dari Pajak Sarang Burung Walet, kondisi ini tidak sesuai dengan target yang ditentukan.

\section{Saran}

Pajak Daerah harus semakin di kelola dengan baik, sehingga penerimaan pajak bisa berperan dalam pembangunan di Wilayah Kabupaten Minahasa Utara serta Pemerintah Kabupaten Minahasa Utara harus melakukan sosialisasi kepada masyarakat tentang peraturan membayar pajak. Dengan pahamnya masyarakat tentang pajak, maka akan membawa dampak positif untuk pembangunan di Daerah Kabupaten Minahasa Utara.

\section{DAFTAR PUSTAKA}

Brotodihardjo, Santoso R. 2011. Penagihan Pajak. Pajak Pusat dan Pajak Daerah. Bogor; Ghalia Indonesia.

Pemerintah Republik Indonesia. 2011. Undang-Undang No. 28 Tahun 2009 tentang Pajak Daerah, Jakarta.

Rochmat Soemitro. 2012. Perpajakan Teori. Bandung; Graha Ilmu. 